\title{
THE VALUE OF CRE IN THE FORMULATION AND IMPLEMENTATION PROCESS OF REAL ESTATE STRATEGIES IN A COMPANY
}

\author{
Jan Konowalczuk, PhD. \\ Department of Investments and Real Estate \\ University of Economics in Katowice \\ e-mail: jan.konowalczuk@ue.katowice.pl \\ Tomasz Ramian, PhD. \\ Department of Investments and Real Estate \\ University of Economics in Katowice \\ e-mail: tomasz.ramian@ue.katowice.pl
}

\begin{abstract}
One of the fundamental ways in which an advantage over competitors can be gained in business is to develop real estate portfolios in such a way that will lead to an increase in market share and value for shareholders. This serves as justification for the formulation and implementation of specific real estate strategies regarding the best manner in which to use CRE, make decisions regarding restructuring, and carry out necessary development projects, taking into account the criteria of: location, time, and procurement options.

This paper presents the formulation and realization of real estate strategies, focusing on the use of the category of property value. Moreover, the authors formulate a possible classification of CRE, which is useful from the perspective of real estate strategies, in addition to identifying and evaluating different types of property values which can be used for real estate strategies. For the majority of operational properties, these categories differ from market value. The last part of the publication provides a reference of selected valuation methods used to determine the value of CRE in the context of formulating and implementing real estate strategies.
\end{abstract}

Keywords: CRE, CRE appraisal, corporate real estate strategy.

JEL Classification: G00.

Citation: Konowalczuk J., Ramian T, 2014, The value of CRE in the formulation and implementation process of real estate strategies in a company, Real Estate Management and Valuation, vol. 22, no. 1, pp. 61-71.

DOI: 10.2478/remav-2014-0008.

\section{Introduction}

Companies today create and maintain a competitive advantage in many functional areas of their line of business, such as human resources, information technology and real estate. In modern economic literature, the term "Corporate Real Estate" (CRE), in the narrow sense, is used to mean the operational real estate of companies dealing with manufacturing or services. In a broader sense, CRE refers to all controlled property, regardless of title and regardless of whether it is used for operating activities or as an investment. The inclusion of investment property in the definition of CRE is justified by the observation of business practices in which companies hold investment properties in their portfolios for various reasons (see LIOW, OOI 2004). 
The authors assume the hypothesis that both at the stage of real estate strategy development (formulation) as well as during its implementation and appraisal, it is necessary to understand the different types of real estate values. This is one of the basic criteria for carrying out the required analysis and evaluation of results. With regard to investment properties, the market value as a basis for valuation, in effect, solves any valuation issues. On the other hand, operational properties are very rarely directly related to the real estate market. The incidental nature that characterizes these properties in terms of contact with the market and the uniqueness of this type of CRE results in the need for the application of other types of values. The purpose of this article is to present the issues relating to operational values of CRE as estimated for the needs of real estate strategies on the theoretical level, related to the basis of value, and at the utility level regarding the suitability of each method, along with a proposal for classifying CRE.

\section{Real estate strategy - the process of formulation and implementation}

The term "strategy" in relation to real estate refers to a deliberate plan of action relating to a company's property portfolio. The implementation of real estate strategies - leading to continued portfolio optimization - can be a source of competitive advantage for a company. The implementation of adopted CRE strategies at an operating level takes place through the management of individual properties or groups of properties. Real estate strategy includes:

1) location decisions,

2) choosing between different forms of CRE control - ownership or other rights,

3) determining the manner in which it is organized and the organizational structure for CRE management,

4) determining the basis for real estate decision-making,

5) creating conditions allowing for the highest and best use,

6) implementing procedures for monitoring and performance evaluation.

In the available literature (WILLS, 2008; HAYNES, NUNINGTON 2010; ROULAC 2005 and others), there is a general agreement that CRE strategies must be created in the context the general business strategy. Hence, an in-depth knowledge and understanding of the foundations of business activities and plans for its development and expansion are often the starting points and always the benchmarks for CRE strategies. Figure 1 shows the process of formulating real estate strategies. It can be divided into the following stages: (1) the property's characteristics, (2) the property users' characteristics, (3) the objectives of the property users, (4) the institutional arrangement of the property market, (5) the context provided by the external world in which the property manager must operate, and (6) performance evaluation.

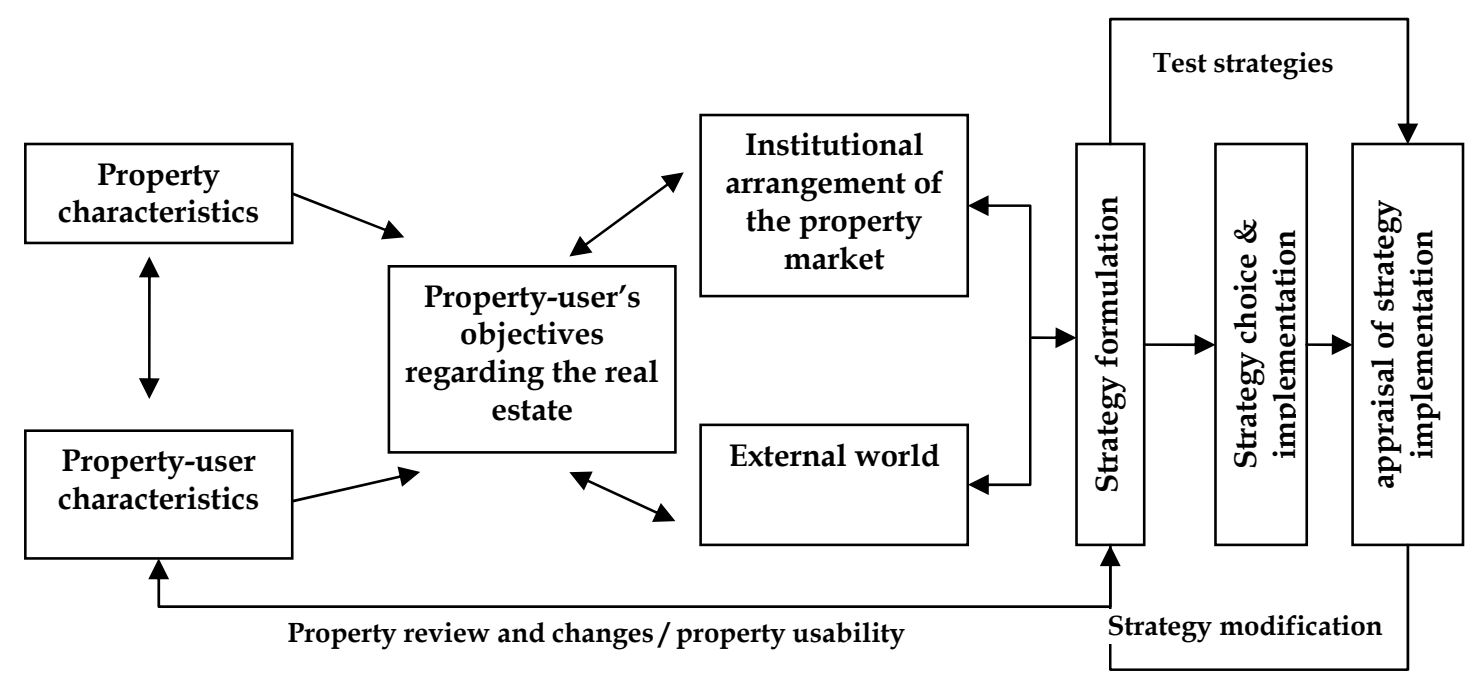

Source: own work.

Real estate analysis refers to the basic technical, legal and financial parameters. The description of a given property must include the following:

- physical/technical aspects of the land and buildings, 
- title to the property and rights associated with the property (including obligations and liabilities),

- the value of the property in terms of operating assets,

- its function with regards to business activities.

At the stage of real estate characterization, it is important not only to determine the property's current market value, but also to assess the potential for development, taking into account possible development activities. In the first stage, information about past, current and expected influence, operating expenses and capital expenditures are collected and analyzed. This allows for the evaluation of the wear and tear of a property and the estimation of value.

The description of a property's users refers to the identification of their preferences, expectations, demands, appraisals, etc., with regards to the property. However, the definition of a user is, in this case, interpreted very broadly and encompasses all stakeholders; for example, when taking a property with a shopping center, a user can be the land-owner, investor, developer, tenant and a tenant's client. In many cases, this can be a specific section of the local community, authorities, institutions and other companies. Such an extensive analysis is warranted, particularly in the case of development plans for a property which will also affect the neighborhood and/or surroundings.

Upon completing the first two stages of the process, it is necessary to confront the state of the property and its potential with the organization's objectives and strategic plans. This makes it possible to determine the use of individual properties (or groups of properties) that best serves a company's strategic objectives. This may impact decisions to dispose of surplus property, modernize existing facilities or acquire new properties. The next step is to analyze the legal and institutional conditions and thus, the legal possibility/permissibility of the property's planned utilization and the implementation of the planned development projects. As the real estate market is quite heavily regulated, this refers to all laws and regulations affecting the use of the property.

The external world refers to the economic, financial, social, and tax aspects of the real estate market and the economy (EDWARDS, ELLISON, 2004). Based on the comprehensive analysis of internal factors and the market environment, it is possible to formulate certain real estate strategies for individual properties, groups of properties or even an entire CRE portfolio. Literature lists a number of real estate strategies, including: reduced costs, increased flexibility, increased productivity, increased employee satisfaction, increased innovation, and increased asset value (LINDHOLM, 2008; KONOWALCZUK, RAMIAN 2009). Companies typically do not limit themselves to utilizing just one strategy, preferring to realize several simultaneously. The implementation of real estate strategies involves many investment, operational and organizational decisions concerning the property. In many cases, the essential decision-making criterion is in the property's market or use value. It should also be noted that managers of CRE portfolios often use external valuations. This takes place in, for example (MANSFELD 2009):

- the acquisition of new units,

- the replacement of existing inadequate holdings possibly at lease end,

- the disposal of units held in legacy portfolios,

- the disposal of surplus operational space.

Market value assessment may be necessary for many external reasons, such as a security or tax liabilities. However, calculating the investment or use value, which leads to specifying a property's worth, is often very useful and is actually frequently used at the property characterization stage, during the decision-making process regarding modernization and expansion, as well as when comparing the current value in terms of the different ways of controlling a property (ownership vs rental). The decision to "rent or buy" a given property must be preceded by an analysis of many strategic and operational factors, as well as financial resources. This will be dependent on the real estate market cycle (sales prices, rents), the tax burden of both variants, and the availability and cost of external capital and accounting regulations (the impact of the purchase/lease on a company's profit, its assets and liabilities). Real estate acquisition is linked to long time periods and high transaction costs (HAYNES, NUNNINGTON, 2010). In instances where the analysis of strategic factors does not provide a clear answer, discounted cash flow analysis is applied, which leads to an estimate of the NPV for both options.

It is worth keeping in mind that the process of formulating and implementing a corporate and real estate strategy is a continuous process, and generally cyclical for planning purposes. Extensive 
changes in the environment may necessitate the substantial reformulation of corporate strategies and lead to changes in the CRE portfolio (restructuring, outsourcing real estate functions and services, changes in location). Real estate portfolios in companies need to be physically (adaptability), functionally and financially flexible (ROULAC 2005).

From the perspective of the process of formulating and implementing real estate strategies, the creation of a classification method is critical, as it affects the majority of stages within the process, including: valuation methods and methods of appraising results.

\section{CRE classification for the purpose of real estate strategies}

CRE assets are a heterogeneous group in terms of physical and legal characteristics, which results in their diverse usability described by economic characteristics. In addition, they perform different functions within the company. This results in the need to implement a multi-level classification, taking into account many different criteria. Apart from classifications based on formal criteria regarding the institutional and legal form of a property, the rights to it or its physical characteristics (see KONOWALCZUK 2009), the usefulness of the economic use criterion to the issues under consideration needs to be addressed. Formally, this refers to CRE accounting principles in financial statements as business assets for the purpose of measuring the value of the capital involved. Polish publications most often distinguish between four types of registered properties: operational (general purpose and specialized), surplus, investment (capital, rent) and working (see MĄCZYŃSKA AND OTHERS 2004; FORYŚ 2006; KONOWALCZUK 2009). With regard to the requirements of European Valuation Standards 2012 (EVS 2012), this list should be augmented to include property controlled under operating or capital leases.

The advantage of this classification is its formal nature and practical aspect with reference to the professional standards for determining fair value for financial reporting at a national (PKZW 2008, standard KSWS 2), European (EVS 2012, the standard EVA 1) and global level (IVS 2011, standard IVS 300 and RICS Valuation Standards 2012, GN2, GN3, GN6). The effect of this is conceptual explicitness, which is crucial for scientific discussion. Today, with a globalised economy, this type of classification is a response to the requirements of international accounting standards/international financial reporting standards (IAS/IFRS) introduced in the European Union by Commission Regulation (EC) No. 1725/2003 of 29 September 2003, adopting specific international accounting standards in accordance with Regulation (EC) No 1606/2002 (EVS 2012, EVA1 Valuation for the Purpose of Financial Reporting, p.1.4.).

Issues regarding strategic decision-making and the measurement of capital in terms of real estate need to take into account the requirements of several basic accounting standards. These most often refer to: IAS 16 Tangible fixed assets, IAS 17 Leases, and IAS 40 Investment property. However, IAS 2 Stocks, IFRS 6 Exploration for and Evaluation of Mineral Resources, IAS 11 Construction Contracts, IAS 41 Agriculture and IFRS 13 are no less important. This formal accounting treatment of CRE serves to highlight the extremely high complexity of the issue regarding its classification.

With classification augmented by property leasing, it should be noted that there is still a lack of the recognition of other contracts, such as traditional leaseholds/leases, in record-keeping. However, in the opinion of some experts, changes in IAS aimed at recognizing various lease agreements (including operating, capital, leaseback leases, etc.) on the balance sheet are expected in the future (HAYNES, NUNNINGTON 2010; NiCK 2003).

The classification presented at the beginning is viable and appropriate from an empirical perspective (KOTARBIŃSKI 1961). Its formal correctness requires, first of all, the verification of fulfilling the logical condition regarding the singularity of criterion (in this case the economic use criterion), or otherwise adopting the sole criterion - application in business. The remaining logical criteria for completeness and disjointness are often difficult to meet, an example of this being an office building used in equal parts for commercial purposes and as an investment, and operational land sometimes used for storage, though generally constituting a surplus. Of course, the correct real classification should be characterized by the highest level of compliance with the criterion of completeness and disjointness, without creating difficulties in its practical usage.

The intended practical goal is to reorganize the classification criteria into the three basic proposed criteria: entitative, objective, and market, while bearing in mind, of course, that any attempt to systematize CRE needs to be real and viable. Therefore, it is possible for some of the conditions of 
completeness and disjointness not to be met. Table 1 presents a proposal for the identification of criteria relevant to the development of a systematic CRE scheme up to the third level of classification.

An example of a useful classification of CRE strategies, based on the criterion of hierarchy and, at the same time, utilizing the criterion of record-keeping, is a proposal presented by P.C. Willis (WILLS 2008). This proposal sorts properties in decreasing importance in terms of real estate strategies, including the following types of CRE:

Selected property classification criteria essential for CRE

Table 1

\begin{tabular}{|c|c|c|}
\hline Criterion & Principle & $\begin{aligned} \text { Type of property } \\
\end{aligned}$ \\
\hline \multirow{4}{*}{ 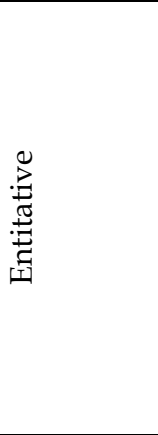 } & Type of economy & $\begin{array}{l}\text { a) household } \\
\text { b) business } \\
\text { c) state } \\
\text { d) other public entity }\end{array}$ \\
\hline & Legal framework & $\begin{array}{l}\text { a) legal entity } \\
\text { b) natural person } \\
\text { c) non-legally registered entity }\end{array}$ \\
\hline & Accounting & $\begin{array}{l}\text { a) recorded } \\
\text { c) non-recorded }\end{array}$ \\
\hline & Hierarchy & $\begin{array}{l}\text { a) main (strategic) } \\
\text { b) secondary }\end{array}$ \\
\hline \multirow{9}{*}{.$\overbrace{\substack{0 \\
0}}^{0}$} & Legal exclusivity & $\begin{array}{l}\text { a) ownership and hereditary tenure } \\
\text { b) limited property rights } \\
\text { c) obligations }\end{array}$ \\
\hline & Socio-economic purpose & $\begin{array}{l}\text { a) earmarked for a specific purpose in the } \\
\text { urban plan (MPZP), or an equivalent } \\
\text { document } \\
\text { b) purpose in urban planning or other } \\
\text { document regarding protection } \\
\text { c) without a defined purpose }\end{array}$ \\
\hline & Physical complexity & $\begin{array}{l}\text { a) single } \\
\text { b) complex } \\
\text { c) group }\end{array}$ \\
\hline & Existence of land improvement & $\begin{array}{l}\text { a) improved properties } \\
\text { b) vacant land }\end{array}$ \\
\hline & Real estate element type & $\begin{array}{l}\text { a) urbanized } \\
\text { b) non- urbanized }\end{array}$ \\
\hline & Wear and tear & $\begin{array}{l}\text { a) depreciable } \\
\text { b) non-depreciable }\end{array}$ \\
\hline & Physical separation & $\begin{array}{l}\text { a) divisible } \\
\text { b) non-divisible }\end{array}$ \\
\hline & Legal separation & $\begin{array}{l}\text { a) divisible } \\
\text { b) non-divisible }\end{array}$ \\
\hline & Use/usage & $\begin{array}{l}\text { a) used (being used) } \\
\text { b) not-used }\end{array}$ \\
\hline \multirow{6}{*}{ 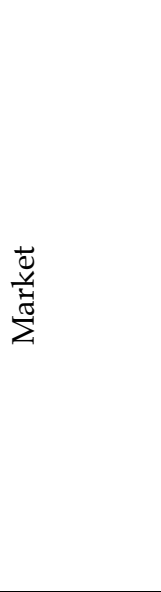 } & Availbility/ Marketability & $\begin{array}{l}\text { a) available/marketable } \\
\text { b) unavailable/unmarketable }\end{array}$ \\
\hline & Market activity & $\begin{array}{l}\text { a) on the market } \\
\text { b) rarely on the market } \\
\text { c) off the market }\end{array}$ \\
\hline & $\begin{array}{c}\text { Type of dem and/or market } \\
\text { Delineation }\end{array}$ & $\begin{array}{l}\text { a) local } \\
\text { b) regional } \\
\text { c) national } \\
\text { d) international }\end{array}$ \\
\hline & Profitability & $\begin{array}{l}\text { a) commercial } \\
\text { b) non-commercial }\end{array}$ \\
\hline & Substitutional & $\begin{array}{l}\text { a) able to be substituted } \\
\text { b) unable to be substituted }\end{array}$ \\
\hline & Sensitivity & $\begin{array}{l}\text { a) sensitive } \\
\text { b) not sensitive }\end{array}$ \\
\hline
\end{tabular}




\begin{tabular}{cll}
\hline Criterion & \multicolumn{1}{c}{ Principle } & \multicolumn{1}{c}{ Type of property } \\
\hline The Highest and Best Use analysis & $\begin{array}{l}\text { a) The highest and best } \\
\text { b) not highest and best }\end{array}$ \\
\hline \multirow{2}{*}{ Potential for value changes } & $\begin{array}{l}\text { a) typical } \\
\text { b) special/particular }\end{array}$ \\
\hline
\end{tabular}

Source: own work.

- strategic property - necessary for the control of operational activity and the realization of longterm strategies,

- landmark, flagship property - assets owned and controlled by ownership and essential for long-term and medium-term strategies,

- core property - assets owned or controlled by the lease, necessary for the implementation of medium-term strategies; may be industrial or commercial properties, or industrial equipment,

- peripheral property - assets necessary for the control of non-cyclical operations; most often leased,

- surplus property - assets not necessary for the control of operational activity..

From a strategic perspective, the significance to the core business and the manner in which it conforms to the ongoing and planned strategies is crucial for the utility of the property to the company. However, classification based, to some extent, on accounting standards has certain advantages. Issues regarding CRE relate to the activities of a company, and international accounting standards should be considered as a viable and terminologically consistent source. This is why treating these standards as a starting point for creating classification is entirely appropriate. In addition, the implementation of real estate strategies and their evaluation of a company must be integrated with the accounting system. This allows for the integration of information systems for the planning, monitoring and evaluation of activities.

\section{Conditions for identifying various types of CRE values}

Determining the value of a property can be analyzed from both a practical and theoretical perspective. Giving priority to the practical perspective is not coincidental, particularly in Poland, which has undergone very strong legal formalization in terms of property valuation - linked to a state system of vocational competency and the standardization of professional valuation activities (see: KONOWALCZUK 2011a). The practical aspect of valuation is associated with the creation of standards, which are usually formulated in accordance with the established procedures. These, in turn, take the form of norms which, in countries with established democracies, are established by specialized organizations, such as the RICS (Royal Institution of Chartered Surveyors) and TAF (The Appraisal Foundation). Functioning on the international arena are groups such as TEGoVA (The European Group of Valuation's Associations) and the IVSC (International Valuation Standards Committee).

Valuation principles and standards adopted in different countries are shaped by various circumstances, i.e., socio-political, economic and legal. This results in variation in property valuation on a conceptual basis, including the suggested categories of values, and impacts the practical aspects of the functioning of a property valuation system. This diversity is evident when attempts are made to agree on a particular valuation methodology, resulting in a clash between different "schools of valuation" (KUCHARSKA-STASIAK 2012).

Discussions regarding the suitability of individual categories of value for business practice turn back to the sources of valuation theory, such as market objectification, market efficiency, and the search for lasting value. Linking practice with economic theory in terms of valuation results in it seeming more reasonable to use existing valuation practices with regards to CRE strategy rather than attempting to create a separate conceptual basis for evaluation categories used for measurements when attempting to assess alternative strategies. However, it is necessary to analyze standardized real estate evaluation categories used in practice in the context of meeting requirements connected with strategic decision-making in a company. It is worth taking under consideration specific evaluation categories related to groups of aims associated with value management, which include: financial statements (financial reporting and taxes), and economic analyses for the evaluation of investment projects and real options (KONOWALCZUK 2009).

In discussing real estate strategies, the issue of their value can be measured at the level of the financial analysis of investment projects, the task of which is to evaluate the financial implications of the investment decision on the investor. In such terms, appraisal is one of several methods of analysis, 
also called criteria (RAMIAN, KONOWALCZUK 2008). These issues must be placed and linked to the already-functioning concepts of a company's value.

This article assumes that CRE strategy issues will be considered from the perspective of business owners, because the successful implementation of real estate strategies needs to lead to increased shareholder value through increased sales and/or increase profitability (LINDHOLM 2008). However, according to many authors, it is extremely difficult to precisely assess the impact of CRE strategies on the value of a company (ROULAC 2005). The results of research on listed companies with regards to this issue are mixed, i.e., the authors believe that (...) "although CRE impacts on value for shareholders through net operating income and the capital cost, the value of CRE is usually hidden from investors and is not fully reflected in the value of market capitalisation " (LIOW, OOI 2004). This position needs to be regarded as true, as the company's value is affected by many external and internal factors; thus, it is impossible to determine the extent to which it contributes to one isolated aspect of a company. On the other hand, it is possible and necessary to estimate the value of each property in the portfolio, estimating the value of the entire CRE portfolio, assessing in-use, market and investment values, replacement cost, comparative analysis of costs, benefits, cash flow analysis for alternative solutions, and selecting real estate strategies. Even if this does not provide an estimate of market value, it allows for a comparison and, therefore, choosing the best strategy.

The formal practical classification of types of property values applied in Poland is done in accordance with regulatory provisions (Act of 20 August 1997 on real estate) and has been found to be unsuitable for consideration, particularly in relation to replacement cost. In determining replacement cost, the principles of valuation, objectivization, anticipation and substitution (KONOWALCZUK 2009) are not fully applied, and the concept of the highest and best use in terms of market value is still under discussion. For this reason, the national evaluation classification could not be taken into consideration with regards to real estate strategy. However, of the available classifications used in the evaluation process, it was possible to adopt the international valuation standards established by the IVSC. The rationale for this is that IVSC standards offer the highest level of universality and are used in practice by organizations operating at an international level, such as TEGoVA and the RICS. These institutions have generally accepted these standards as the basis for classifying the types of valuations, together with defining and interpreting market value.

The methodological regulations of the International Valuation Standards have, for many years, consistently distinguished one particular category of market value and a selection of non-market values, assuming economic criterion concerning the conditions of market objectivization. This is referred to by the definition of market value, including its interpretation, to the concept of a free market. The selection of non-market values is distinguished negatively in terms of market value by identifying a specified element of the definition that isn't met. It must be noted that the types of nonmarket values change. Figure 2 presents the classification of values according to IVS 2005, indicating the practical types of isolated non-market values of the time.

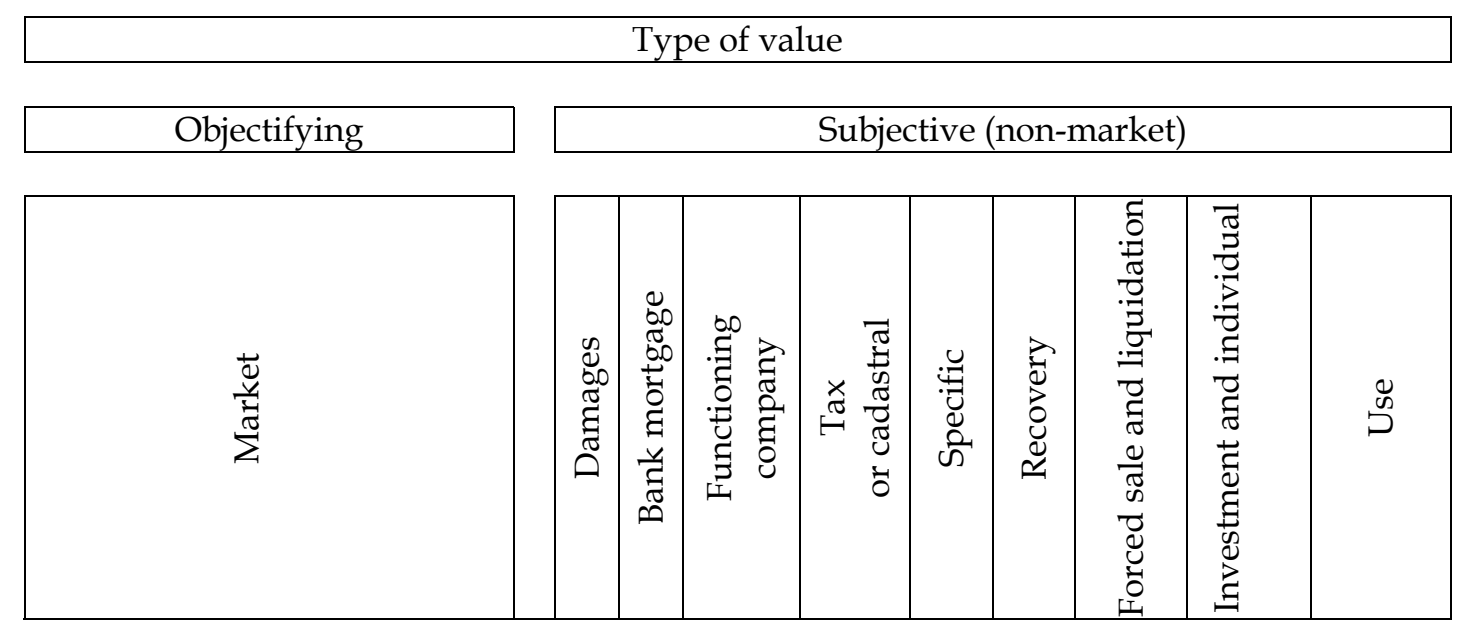

Fig. 2. Types of valuation classifications according to IVS 2005, Source: KONOWALCZUK (2009).

The types of classifications for the purpose of valuation practices have both a variable and specific character. In the 2007 edition of the IVS publication, significant changes in the direction of defining the 
bases of valuation, which are available for selection to meet specific valuation targets, could already be found. The base value is, therefore, set out to ascertain the key assumptions on the basis of which a value is determined, e.g., the hypothetical nature of the transaction, the extent to which the valued component is exhibited on the property market, and the relationship between the parties to the transaction and their motives and actions. In the current 2011 issue of IVS, several categories which form the basis of valuation and other types which do not, have been clearly distinguished. Table 2 presents the types of values that form the basis for IVS 2012 valuation criteria, indicating specificity and definition.

Table 2

Types of values forming the basis for valuation according to IVS 2012

\begin{tabular}{|c|c|c|c|c|}
\hline Principle & Criterion & $\begin{array}{l}\text { Type } \\
\text { of } \\
\text { value }\end{array}$ & Definition & $\begin{array}{c}\text { Property's } \\
\text { distinctive } \\
\text { characteristics }\end{array}$ \\
\hline
\end{tabular}

\begin{tabular}{|c|c|c|c|c|}
\hline \multirow{2}{*}{ 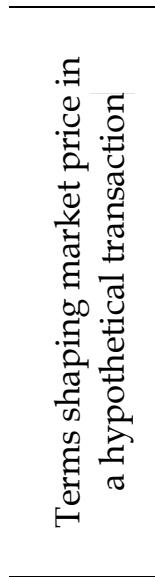 } & $\begin{array}{l}\text { The most probable } \\
\text { price reasonably } \\
\text { obtainable in a } \\
\text { hypothetical } \\
\text { transaction on the } \\
\text { market }\end{array}$ & 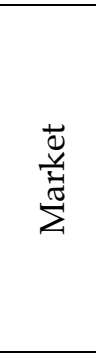 & $\begin{array}{l}\text { The estimated amount that an asset can } \\
\text { achieve on the date of valuation, provided } \\
\text { that the parties are willing to conclude the } \\
\text { agreement and are independent of each } \\
\text { other, act knowledgeably, prudently and } \\
\text { without compulsion, and the property has } \\
\text { been displayed on the market for a sufficient } \\
\text { time period }\end{array}$ & $\begin{array}{l}\text { Entitative, } \\
\text { Subjective and } \\
\text { Market }\end{array}$ \\
\hline & $\begin{array}{l}\text { A price that is } \\
\text { agreed to be fair } \\
\text { between two } \\
\text { particular parties in } \\
\text { the sale of an asset }\end{array}$ & 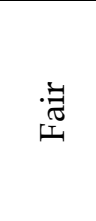 & $\begin{array}{l}\text { The estimated price at which an asset or } \\
\text { liability could be exchanged between } \\
\text { identified, knowledgeable and willing } \\
\text { parties, which reflects the interests of those } \\
\text { parties }\end{array}$ & Entitative \\
\hline \multirow{2}{*}{ 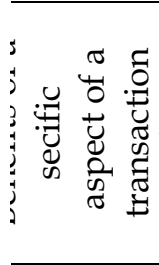 } & \multirow{2}{*}{$\begin{array}{l}\text { The special value for } \\
\text { a particular entity, } \\
\text { which would not be } \\
\text { available to other } \\
\text { buyers on the market }\end{array}$} & 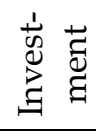 & $\begin{array}{l}\text { The value that a specific asset has for the } \\
\text { current or potential owner, intending to use } \\
\text { it for investment or operational purposes }\end{array}$ & Entitative \\
\hline & & $\begin{array}{l}\bar{\Xi} \\
\text { ֻँّ } \\
\text { के }\end{array}$ & $\begin{array}{l}\text { The amount that reflects the specific } \\
\text { attributes of an asset, which are only of } \\
\text { value to a particular purchaser }\end{array}$ & $\begin{array}{c}\text { Entitative and } \\
\text { Objective }\end{array}$ \\
\hline
\end{tabular}

Source: Own work based on IVS (2011).

According to the 2011 IVS, there are three categories (criteria) and four types of values forming the basis for appraisal. In Table 2, the three categories were aggregated with reference to two general principles for separation. The first rule applies to the conditions of market price formation in a hypothetical transaction, while the other refers to the benefits for the parties of the transaction.

It should also be noted that three of the types of values listed in Table 2 ought to be classified as non-market. As a result, there is still a distinction between one market value and many types of nonmarket values, some of which were included in the basis of valuation.

In addition, the 2012 IVS distinguish different practical types of non-market values which do not constitute the basis for valuation, including:

1) Synergistic value - an additional element of value created by the combination of two or more assets, where the combined value is greater than the sum of those values.

2) The value for the owner, an estimate of the benefits of owning the asset.

3) Values for a particular owner, where the valuation of assets reflects the special factors owing to the entity. In situations where it is required to determine the value for a specific owner, the following is included:

a) justification of investment decisions,

b) analysis of the efficiency of the asset.

4) The value of a single asset depends on its relationship with other assets.

5) Added value gained by creating a portfolio of similar assets.

6) Value in exchange is a hypothetical price. The hypothesis based on which the value is estimated is determined by the purpose of the valuation. It may, therefore, be market and non-market 
value.

7) Fair value in accordance with IFRS, also referred to as fair value for financial statements (in accordance with the concept of market value in IVS 2011).

Of the real estate strategies from the IVS regulations, the values which will be essential are those of market value and investment value, which is used to evaluate an investment's effectiveness. In addition, an assessment of market characteristics regarding usage and potential changes in value is important; following the valuation of each property is an assessment of market characteristics regarding usage and potential changes in value. Should there be an instance of special value, the value for a particular owner, including synergistic value, should be used.

What is very interesting when looking at the assumed definitions is the valuation category of banking-mortgage. This category is not mentioned in IVS, but is the practical non-market value category that European standards are familiar with (see IVS 2012). The usefulness of this category is primarily associated with accounting for the many aspects of appraising the future marketability of a property in the assumed definitions. This appraisal takes into account the long-term characteristics of a property, the normal and specific conditions for the local real estate market, and the current (actual) and alternative uses of the property. Unfortunately, the practice of appraising for such non-market values most often applies to rental investment properties and, as a result, standard solutions are of little use for the appraisal of operational real estate.

EVS 2012 solutions are relevant to the issues of CRE strategy for understanding the contemporary interpretation of market value, which is explained not only by employing the concept of the highest and best use but also by the concept of "hope value" from the British school. This solution is transferred from a very mature British market, which suggests that the conditions of value objectivization allow a certain surplus to be taken into account in the appraisal of market value (as of the day of the valuation), accepted by the buyers (typical?), due to the fact that property possess a specific "mix" of market characteristics pertaining to the assessment of the use and potential changes in value. The surplus refers to the "hope" that the CRE will have the opportunity to change in terms of use, thus increasing in value. This valuation does not need to take into account if the assumed or planned property use is legally permissible.

\section{Conclusions}

Based on this performed analysis it can be concluded that, for the purposes of CRE strategies, standardized types of values, estimated by appraisers, are useful but not sufficient or allencompassing. Thus:

1) For investment, surplus and working properties, it is possible to estimate market and investment value, and this is often sufficient. This results from the fact that these types of properties are more related to the real estate market than the company's activities. Therefore, the established assumptions for valuation, with regards to the condition of the property and the condition of the real estate market, ensure the objectivity of market value while investment value is able to take into account the entity's specific requirements and objectives. However, it ought to be noted that both value categories reflect only temporary relationships between supply and demand on the property market and, therefore, may be subject to significant changes in the short term, while from a strategic point of view, the value may be significant in the long-term.

2) For operating properties, in addition to market and investment value, use value is essential. This reflects the benefits of a property to the functioning of an enterprise (as a going concern) as part of an organized structure of assets. This kind of value, however, does not refer directly to the real estate market, but the market in which the company is active. The advantage of use value is its stability, which excludes short-term fluctuations on the property market.

3) In the case of specialist operational real estate, owing to the lack of comparable market data (prices, income, rates of return), it may be possible to estimate the use value by employing the DRC method. This appraisal should be augmented by valuations based on estimates of NPV using discounting cash flow analysis.

Formulation and implementation of CRE strategies requires a comprehensive approach to the issue of property value, beyond that used in practice by property appraisers. This applies to both types of defined values and valuation methods, which in this case should not be highly formalized. Valuation 
methods should be more individualized - by taking into account the state of the company, and tailored to the formulated aims of CRE strategies.

In addition, it is necessary to take into account (estimate) strategic depreciation (obsolescence) existing when a given property doesn't fit into the company's current and future business strategies. At the level of analyzing a particular property in the CRE portfolio, it is reasonable to use the concept of the highest and best use of property together with "hope value", supplemented by an analysis of strategic importance, that is the significance of the real estate for business strategy, which refers back to the presented strategic classification of CRE.

\section{References}

EDWARDS V., ElLISON L., 2004, Corporate Property Management: Aligning Real Estate With Business Strategy. Blackwell Publishing, Oxford, Kindle Edition.

European Valuation Standards 2012 (EVS 2012). The European Group of Valuers' Associations (TEGoVA), Printed in Belgium by Gillis nv/sa.

FORYŚ I. (RED), 2006, Zarządzanie nieruchomościami komercyjnymi, Poltext, Warszawa.

FRENCH, N., 2003, The price of space: the convergence of value in use and value in exchange. Journal of Property Investments and Finance,21(1).

HAYNES B., NUNNINGTON N.,2010, Corporate Real Estate Asset Management: Strategy and Implementation. Taylor \& Francis. Oxford, Kindle Edition.

International Valuation Standards 2011 (IVS 2011). International Valuation Standards Council, London.

KONOWALCZUK J. RAMIAN T., 2009, Strategie nieruchomościowe przedsiębiorstw $(\mathrm{w})$ Strategie inwestowania na rynku nieruchomości, red. H. Henzel, Wydawnictwo Akademii Ekonomicznej, Katowice.

KONOWALCZUK J., 2009, Wycena nieruchomości przedsiębiorstw, CH Beck, Warszawa.

KONOWALCZUK J., 2011, Ryzyko wywtaszczenia nieruchomości przedsiębiorstw. W: Inwestycje i nieruchomości - wybrane zagadnienia. Zeszyty Naukowe „Studia Ekonomiczne” nr 74. Red. nauk. K. Marcinek. Wydawnictwo Uniwersytetu Ekonomicznego, Katowice.

KonOWALCZUK J., 2011a, Standaryzacja wyceny nieruchomości w Polsce. Świat Nieruchomości nr 76/2011. Kraków.

KOTARBIŃSKI T., 1961, Elementy teorii poznania, logiki formalnej i metodologii nauk. Wrocław - Warszawa Kraków: Zakład Narodowy Imienia Ossolińskich - Wydawnictwo.

KUCHARSKA- STASIAK E., 2012, Wprowadzenie do wydania polskiego. Międzynarodowe standardy wyceny 2011. PFSRM, Warszawa.

LiNDHOLM, A.L., 2008, A constructive study on creating core business relevant CREM strategy and performance measures. Facilities,26(7/8).

LiOW K.H., OOI J.T.L., 2004, Does corporate real estate create wealth for shareholders? Journal of Property Investments and Finance,22(5).

MĄCZYŃSKA E., I INNI., 2004, Ile warta jest nieruchomość, Poltex, Warszawa.

MANSFIELD, J.R., 2009, The valuation of sustainable freehold property: a CRE perspective. Journal of Corporate Real Estate. 11(2).

Międzynarodowe Standardy Sprawozdawczości Finansowej (MSR/MSSF 2004), wydanie polskie, 2004, IASCF Londyn.

OsUCHOWSKI W., 1985, Rzymskie prawo prywatne. Zarys wykładu. Państwowe Wydawnictwo Naukowe Warszawa.

PiKe R., NeAle B., 1999, Corporate finance and investment. Decisions and strategies. Prentice Hall Europe.

Powszechne Krajowe Zasady Wyceny (PKZW 2008). Polska Federacja Stowarzyszeń Rzeczoznawców Majątkowych. Warszawa 2008, www.pfva.com.pl.

RAMIAN T., KONOWALCZUK J., 2008: Kryteria podejmowania decyzji inwestycyjnych na rynku nieruchomości (w ) Inwestycje na rynku nieruchomości, red. H. Henzel, Wydawnictwo Akademii Ekonomicznej, Katowice.

RAPPAPORT A., 1986, Creating Shareholder Value: The New Standard for Business Performance, Macmillan.

ROULAC, S., 2005, Corporate strategic decision making. A comparative analysis of companies in the industrial and non-industrial sectors. Journal of Property Investments and Finance, 23(4).

Rozporządzenie Komisji (WE) No. 1725/2003 z 29 września 2003 r. przyjmujące określone międzynarodowe standardy rachunkowości. 
Standardy Wyceny RICS 2012 (Wydanie polskie), The Royal Institution of Chartered Surveyors, Surveyorscort Westwood Business Park, Wielka Brytania.

The appraisal of real estate. Third Canadian edition, 2008, Appraisal Institute of Canada, 20.5.

WILLS P.C., 2008,: Corporate real estate practice in Australia. Journal of Real Estate, 10 (1). 